\title{
Development of Innovative Heating and Cooling Systems Using Renewable Energy Sources for Non-Residential Buildings
}

\author{
Elisa Moretti $^{1, *}$, Emanuele Bonamente ${ }^{2}$, Cinzia Buratti ${ }^{2}$ and Franco Cotana ${ }^{2}$
}

1 CIRIAF - Interuniversity Centre of Research on Pollution by Physical Agents, University of Perugia, Via Duranti 63, Perugia 06125, Italy

2 CRB - Biomass Research Centre, University of Perugia, Via Duranti 63, Perugia 06125, Italy; E-Mails: bonamente@crbnet.it (E.B.); cinzia.buratti@unipg.it (C.B.); cotana@crbnet.it (F.C.)

* Author to whom correspondence should be addressed; E-Mail: elisa.moretti@unipg.it; Tel.: +39-075-5853694; Fax: +39-075-5853697.

Received: 29 August 2013; in revised form: 26 September 2013 / Accepted: 27 September 2013 / Published: 9 October 2013

\begin{abstract}
Industrial and commercial areas are synonymous with high energy consumption, both for heating/cooling and electric power requirements, which are in general associated to a massive use of fossil fuels producing consequent greenhouse gas emissions. Two pilot systems, co-funded by the Italian Ministry for the Environment, have been created to upgrade the heating/cooling systems of two existing buildings on the largest industrial estate in Umbria, Italy. The upgrade was specifically designed to improve the system efficiency and to cover the overall energy which needs with renewable energy resources. In both cases a solar photovoltaic plant provides the required electric power. The first system features a geothermal heat pump with an innovative layout: a heat-storage water tank, buried just below ground level, allows a significant reduction of the geothermal unit size, hence requiring fewer and/or shorter boreholes (up to $60 \%-70 \%$ ). In the other system a biomass boiler is coupled with an absorption chiller machine, controlling the indoor air temperature in both summer and winter. In this case, lower electricity consumption, if compared to an electric compression chiller, is obtained. The first results of the monitoring of summer cooling are presented and an evaluation of the performance of the two pilot systems is given.
\end{abstract}

Keywords: heating and cooling; system monitoring; renewable energy sources (RES); geothermal heat pumps; heat-storage systems; biomass boiler; absorption machine 


\section{Introduction}

Non-residential buildings are characterized by high average energy consumptions, both for heating/cooling systems and electric appliances. On average, the electric mix is dominated by fossil fuels, causing significant greenhouse gas emissions. The depletion of fossil fuel reserves and the pressing target for $\mathrm{CO}_{2}$ emission reduction is pushing the international community to search for valid alternatives to conventional fossil resources [1]. Worldwide energy policies encourage both the energy savings from passive solutions and the exploitation of renewable energies (solar and wind energy, geothermic, biomass and bio-fuels, and fuel cell technologies) [2-9]. The European Community [10] specifically promotes the transition to nearly-zero energy buildings [11-13], characterized by high energy performance and renewable energy exploitation.

Within the commercial sector, office and retail buildings are those associated to highest consumptions, spanning in the range $200-300 \mathrm{~kW} \mathrm{~h} / \mathrm{m}^{2}$ year; a major fraction (approx. 40\%-50\%) of the energy consumption is due to heating, ventilation and air conditioning (HVAC) usage [14]. It is straightforward that any optimization of the performances of heating and cooling systems could produce relevant environmental benefits. Nowadays, the national market for heating/cooling systems for commercial buildings is dominated by small split-units with a cooling capacity ranging from $2 \mathrm{~kW}$ to $6 \mathrm{~kW}$, which are available at very low prices. Those systems, however, require a huge quantity of primary energy, increasing their environmental impact and producing severe grid overload problems. In this context, alternative air-conditioning units, run on renewable energies, represent a promising solution [15]. Local biomass resources, in particular, have an attractive potential, because they are substantially neutral with respect to the $\mathrm{CO}_{2}$ emissions, they generate much lower emissions of $\mathrm{NO}_{x}$ and $\mathrm{SO}_{2}$ than that of fossil fuels, and they are available at competitive prices in many areas [16]. In addition, in some situations, geothermal heat pumps are also a promising technology for heating and cooling systems in buildings $[17,18]$.

It is against this background, the Biomass Research Centre (CRB) of the University of Perugia, Italy, in collaboration with the Municipality of Perugia and a local consortium of craft and manufacturing companies (Consorzio Le Fratte), designed and implemented two pilot heating/cooling systems for commercial buildings hosting offices and retailers. The size and the layout of the two systems are a representative case of future upgrades, following this case study, both for residential and non-residential buildings. The development was co-funded by the Italian Ministry for the Environment within the SCER (the Italian acronym for Development of a new Renewable-Energy Conditioning system for commercial buildings) research project. The two systems were set up with the goal of upgrading previously-existing buildings, located on the most important commercial/industrial estate in Umbria, situated in central Italy, supplying them with high-efficiency heating and cooling systems, using a mix of renewable energies. In the first case, a geothermal heat pump uses the ground as a heat source/sink to provide space heating and cooling. The energy and environmental advantages of this solution compared to conventional air conditioning is deeply discussed in the literature [19]. In the paper an innovative layout is proposed in order to increase the efficiency and to reduce installation costs: a heat-storage water tank of an appropriate size was included, buried just below ground level, exchanging heat independently with the geothermal side and the heat-pump side. The second prototype system features a chip-wood/pellet boiler coupled with an absorption chiller machine. Many applications 
of absorption air-conditioning have been investigated, mostly referred to solar energy exploitation rather than biomasses [20,21]. In both cases, roof-top solar photovoltaic plants supply the electric energy.

The performance of the two pilot systems is monitored with a custom data acquisition system and the first results of summer cooling monitoring are presented in this paper, in order to evaluate key-performance indicators and benefits compared to conventional systems.

\section{The Case Study}

\subsection{The Investigated Area and the Selected Buildings}

The target area, Sant'Andrea delle Fratte, is the most important commercial/industrial estate in Umbria, in central Italy. It is located on the outskirts of the city of Perugia and it currently hosts about 600 different commercial/industrial/manufacturing/service companies. The area has high energy consumption, with about $28 \mathrm{GW}$ h of electric energy required per year (2010 data). Based on a survey, a large number of the companies (about 40\%) have an electric energy consumption of between 10,000 and $50,000 \mathrm{~kW} \mathrm{~h} /$ year. Methane is the most commonly used fuel for heating $(61 \%)$, and cooling is provided by small split-units with a cooling capacity from $2 \mathrm{~kW}$ to $6 \mathrm{~kW}$.

The buildings that were to undergo the renovation process were carefully selected according to the owners' interest in renewable energy use and to building features. Two buildings were selected (Figure 1):

- Building No.1 (Figure 1a): a total volume of $360 \mathrm{~m}^{3}$, used as offices, workshops, and restrooms, is conditioned. The ante-operam state was characterized by mono-split air to air heat pumps, which required approximately $14,000 \mathrm{~kW}$ h of electric energy from the grid;

- Building No.2 (Figure 1b): constituted by different conditioned zones: an exhibition room $\left(318 \mathrm{~m}^{2}\right)$, two offices $\left(24 \mathrm{~m}^{2}\right.$ and $43 \mathrm{~m}^{2}$, respectively), restrooms $\left(12 \mathrm{~m}^{2}\right)$, a dealership $\left(24 \mathrm{~m}^{2}\right)$, and a mechanic's workshop (about $158 \mathrm{~m}^{2}, 7 \mathrm{~m}$ high). The building has a large window area on the exhibition room (about $206 \mathrm{~m}^{2}$ ), with South-East exposure. Before the renovation, mono-split air to air heat pumps were used for cooling in some zones, whereas a methane boiler with fan-coils and radiators provided heating. In this case, the system was undersized, especially in summer, causing temperatures higher than $30{ }^{\circ} \mathrm{C}$ during the hottest days, with evidently uncomfortable conditions for the occupants. Moreover, the mechanic's workshop had no cooling system at all.

Figure 1. The investigated buildings: building (a) No.1 and (b) No.2.

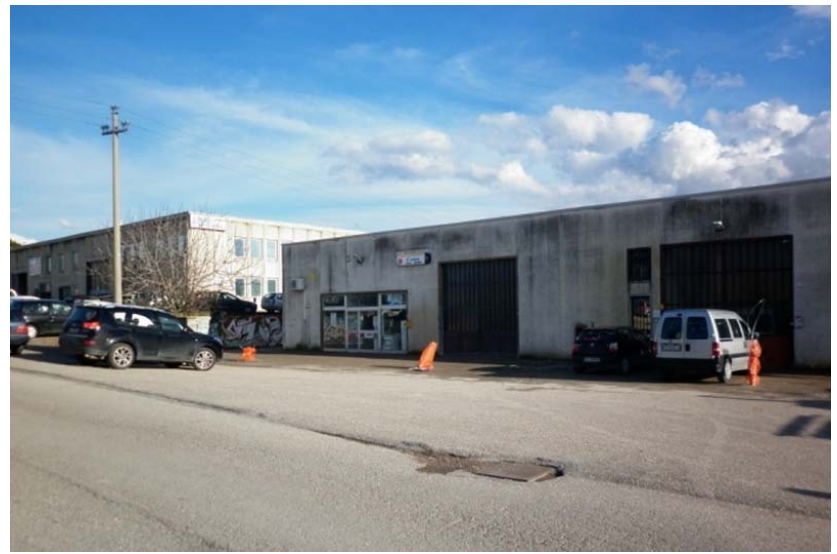

(a)

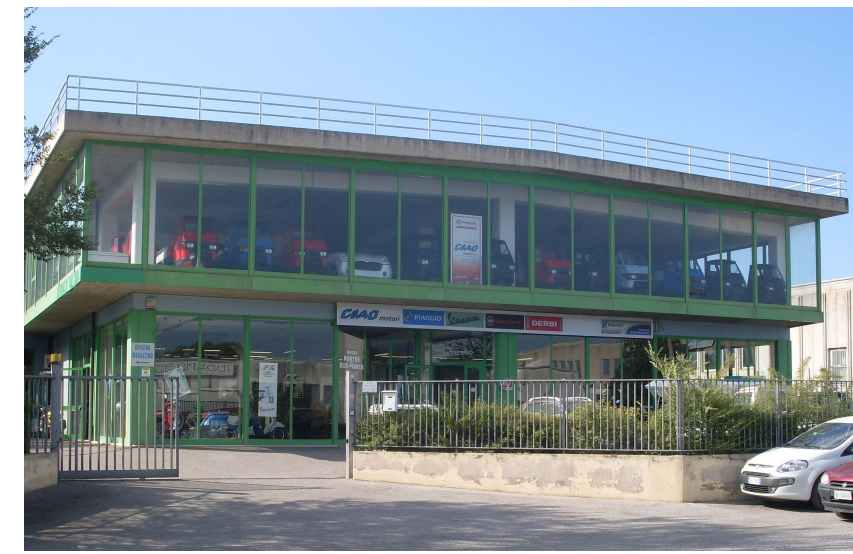

(b) 


\subsection{Heating and Cooling Needs Calculation}

The envelope properties (opaque and transparent surfaces) of both the buildings were characterized with experimental campaigns [22]. The heating and cooling loads (Table 1) were estimated in steady state using the TerMus software package. The results were used to design the new heating/cooling systems, according to the maximum power demand. An external temperature equal to $-2{ }^{\circ} \mathrm{C}$ for winter and to $32{ }^{\circ} \mathrm{C}$ for summer was chosen for the site; appropriate heating/cooling schedule and people occupancy were assumed.

Table 1. Thermal transmittances of the building envelopes.

\begin{tabular}{ccc}
\hline Structure & Building No.1 & Building No.2 \\
\hline Walls & $0.6 \mathrm{~W} / \mathrm{m}^{2} \mathrm{~K}$ & $1.0 \mathrm{~W} / \mathrm{m}^{2} \mathrm{~K}$ \\
Roof & $0.5 \mathrm{~W} / \mathrm{m}^{2} \mathrm{~K}$ & $1.0 \mathrm{~W} / \mathrm{m}^{2} \mathrm{~K}$ \\
Ground & $0.6 \mathrm{~W} / \mathrm{m}^{2} \mathrm{~K}$ & $1.0 \mathrm{~W} / \mathrm{m}^{2} \mathrm{~K}$ \\
Windows & $5.0 \mathrm{~W} / \mathrm{m}^{2} \mathrm{~K}$ & $5.6 \mathrm{~W} / \mathrm{m}^{2} \mathrm{~K}$ \\
\hline
\end{tabular}

The peak energy requirements for building No.1 are $19 \mathrm{~kW}$ for winter heating and $12 \mathrm{~kW}$ for summer cooling, due to the reasonably satisfactory insulation envelope properties and the limited transparent area. For the second building, the maximum power is about $60 \mathrm{~kW}$ in winter and $65 \mathrm{~kW}$ in summer, because of the higher conditioned area and the large single-glazed windows.

A dynamic simulation was performed for building No.1 using the Energy Plus software package [23,24] in order to obtain hourly profiles (Figure 2) and to estimate the maximum daily energy requirement. A maximum of $100 \mathrm{~kW} \mathrm{~h}$ for heating and $70 \mathrm{~kW} \mathrm{~h}$ for cooling is found. The simulations were required for the correct sizing of the innovative geothermal system.

Figure 2. Typical hourly thermal-loads profile of building No.1 for (a) heating and (b) cooling.

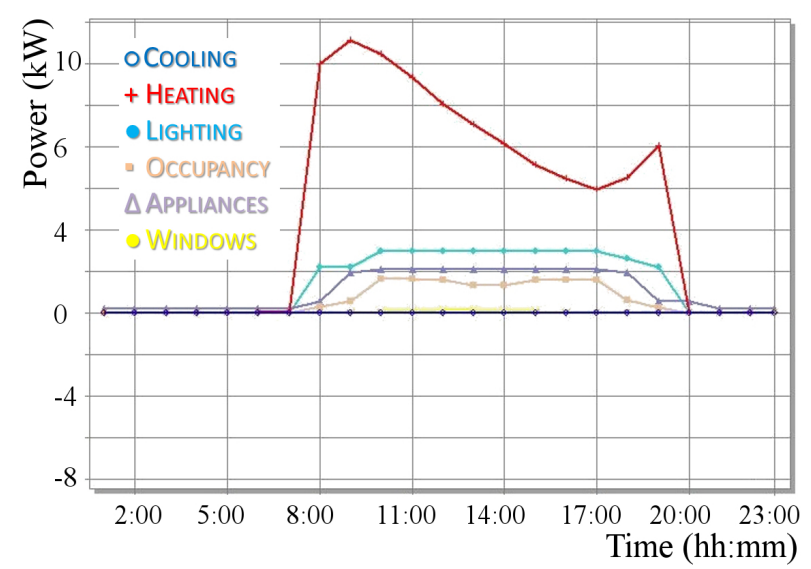

(a)

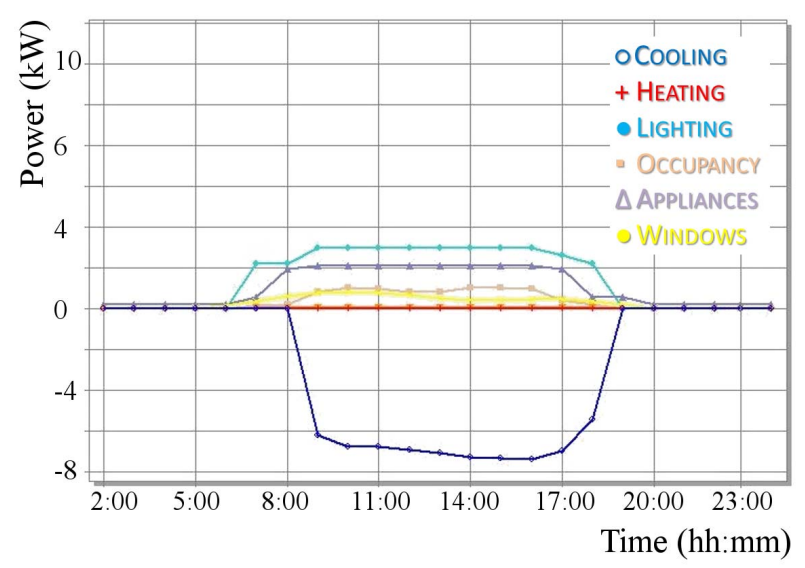

(b)

\section{Methodology: The New Heating/Cooling System Set-Up}

\subsection{The Pilot Heating/Cooling System Ideas}

The renovated heating and cooling systems use a mix of renewable energies: solar energy (from photovoltaic fields), geothermal heat from the ground (using vertical geothermal boreholes) and biomass. 
The first plant (Figure 3a) features a geothermal heat pump, used to efficiently transfer the heat from the ground to the building. In water to water geothermal systems, thermal energy is extracted from the ground usually by vertical closed loops, processed by the heat pump and distributed to the building, using a mix of water and propylene glycol as carrier. Ground-source heat pumps are already widely used to serve residential and commercial buildings, especially in the USA, Europe and Asia, due to their great potential for energy savings in building air conditioning and in reducing $\mathrm{CO}_{2}$ emissions [25-32]. At present, this technology is not yet in widespread use in Italy, especially in the center and south areas, mainly because of the high initial costs (borehole drilling, about $40-55 € / \mathrm{m}$ in Italy). In this application, an innovative layout is proposed. Conventional geothermal heat pumps use the direct heat transfer between the internal unit and the ground, taking place at the same time as heating or cooling is required by the building [31], during daylight hours and according to regular usage schedules of heating/cooling systems. The geothermal resource is hence exploited at its maximum capacity only for a short amount of time, even during coldest/hottest days; nevertheless the borehole sizing is carried out in order to cover the peak power need [33]. A possible optimization of the geothermal field could be obtained introducing a thermal flywheel that decouples the ground-side unit from the heat pump. In the innovative layout, the heat pump is not directly connected to the boreholes, but exchanges heat with an underground tank, filled with water (see Figure 3a).

Figure 3. The proposed heating/cooling systems: (a) geothermal heat pump with heat-storage tank; and (b) biomass boiler with absorption machine; a photovoltaic plant covers electric needs in both cases.

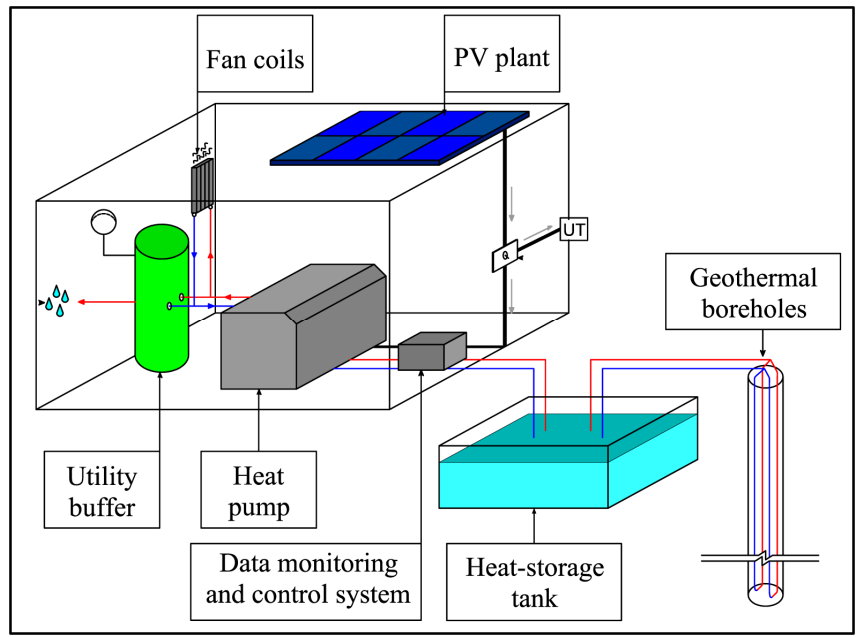

(a)

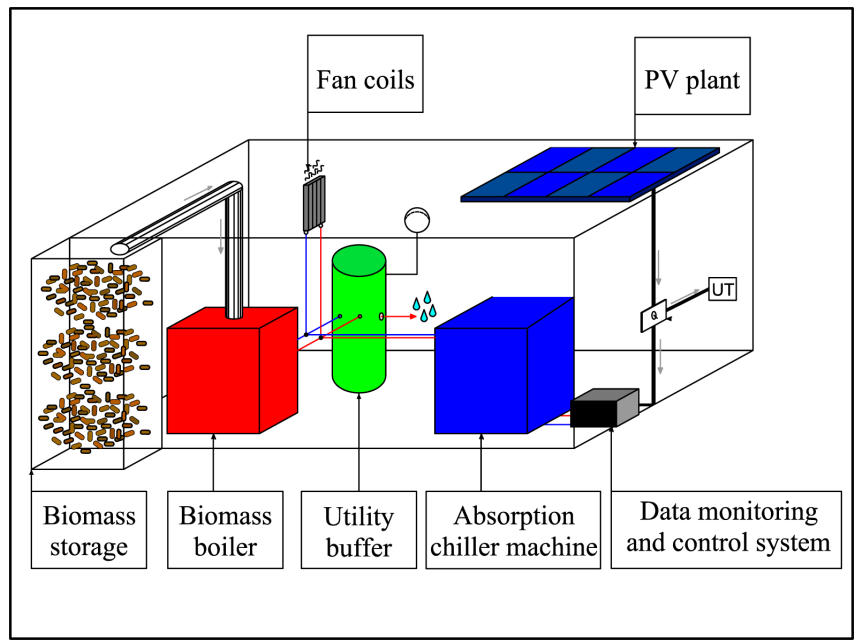

(b)

In the second plant, a boiler, coupled with an absorption machine, provides both heating and cooling, using local wood-based biomass (Figure 3b). When compared to fossil fuels, biomass presents a number of advantages: low sulfur and nitrogen content, generating much lower emissions of $\mathrm{NO}_{x}$ and $\mathrm{SO}_{2}$ than that of conventional fossil fuels; the ash content is very low ( $<1 \%$ in most wood samples); they are a cheap energy source [34-38]. Nowadays, biomass is one of the major energy sources, providing approximately $14 \%$ of the world energy requirements, varying from $9 \%$ to $14 \%$ of the total energy supply in industrialized countries and up to $35 \%-40 \%$ in developing countries [34]. In central Italy, chip wood for boilers with excellent properties (wood size, high heating value, low moisture and 
ash content, etc.) is available at a low cost, especially during summer. Therefore, the heat produced using biomass could be conveniently used for cooling using an absorption machine. The gas, kerosene or electrically driven absorption refrigerators were theoretically and experimentally investigated in the literatures [39-44], also for trigeneration applications and they are widely used both with conventional heat sources and thermal solar energy [20,21]. The innovative approach proposed here is the heat production for the absorption from different renewable resources, such as biomass.

\subsection{System Layout and Implementation}

\subsubsection{Geothermal Heat Pump (GHP) with Heat-Storage Tank for Building No.1}

In building No.1, a $40 \mathrm{kWp}$ photovoltaic polycrystalline plant is installed on the roof and supplies energy to cover the heat pump and other electrical appliance needs. An Elco Aquatop T17CH (Elco Italia S.p.A, Resana, Treviso, Italy) water-to-water heat pump (HP) was chosen to provide heating and cooling power [45]. The unit transfers heat to/from the conditioned rooms via two fluids: a mix of water and propylene glycol on the geothermal side, water on the building side. Given the project conditions a nominal coefficient of performance (COP) of 4.0 and a nominal energy efficiency ratio (EER) of 5.3 could be estimated. The space heating and cooling makes use of fan coils.

To be on the safe side, the sizing of geothermal (GT) boreholes was performed in order to provide the maximum power need, without taking into account the effect of the heat-storage tank: according to the Ground Response Test results (measured power extraction capacity equal to $46.5 \mathrm{~W} / \mathrm{m}$ ), three 120-m-long boreholes were drilled [31,45].

This innovative layout with heat-storage tank was designed on the basis of an energy-balance approach rather than the conventional power-demand approach, where the geothermal field is sized to provide the maximum thermal power demanded by the heat pump; the energy-balance approach instead requires the geothermal unit to only provide the needed energy during a $24 \mathrm{~h}$ cycle. The heat-storage tank sizing was carried out with an energy-balance simulation, taking into account the typical heating schedule for coldest days [45]. The simulation results showed than a $12 \mathrm{~m}^{3} \operatorname{tank}$ ( $2.5 \mathrm{~m}$ high), buried $0.5 \mathrm{~m}$ below the ground level, represents a good compromise and it fulfills both heating and cooling requirements. The heat transfer between the geothermal boreholes fluid and the water in the tank is assured by a properly sized cylindrical-plate heat exchanger, while a second cylindrical heat exchanger is used to transfer heat between the tank and the heat pump [45]; both these two closed circuits are filled with a mix of water (82\%) and propylene glycol (18\%), protecting the system from freezing.

The pilot system is installed in a commercial building currently in business, therefore, special piping was included to bypass the tank and to switch to the standard configuration (Figure 4); this approach could also allow a direct comparison with the performance of a conventional geothermal layout for the same application.

The system could work in two modes:

(1) Conventional mode (Figure 4a): manual three-way valves can be used to bypass the two heat exchangers and the heat pump is directly plugged to the geothermal unit. The HP is turned on 
when the water inside the utility buffer falls below an adjustable temperature set point: when this happens the heat is taken directly from the geothermal unit (three boreholes);

(2) Alternative mode, including the water tank (Figure 4b): the HP works with the same logic, but taking the needed thermal energy from the tank. For example, in heating mode, when the heat pump is started, the tank water temperature starts decreasing. When it falls below a given set value, the reduced-size geothermal unit starts transferring heat from the ground into the tank [using the geothermal pump (GP)]. In this period, the water temperature keeps decreasing, even if at a slower rate. When finally the heat pump is turned off, the geothermal unit continues recharging the tank until the initial set temperature is reached and the system is ready for the next working cycle. The flow rate from the geothermal unit can be changed to simulate different sizing of the boreholes (using one, two, or all the boreholes, at full or partial flow rates).

Figure 4. Geothermal heat pump (GHP) layout: (a) conventional working mode; and (b) alternative working mode.

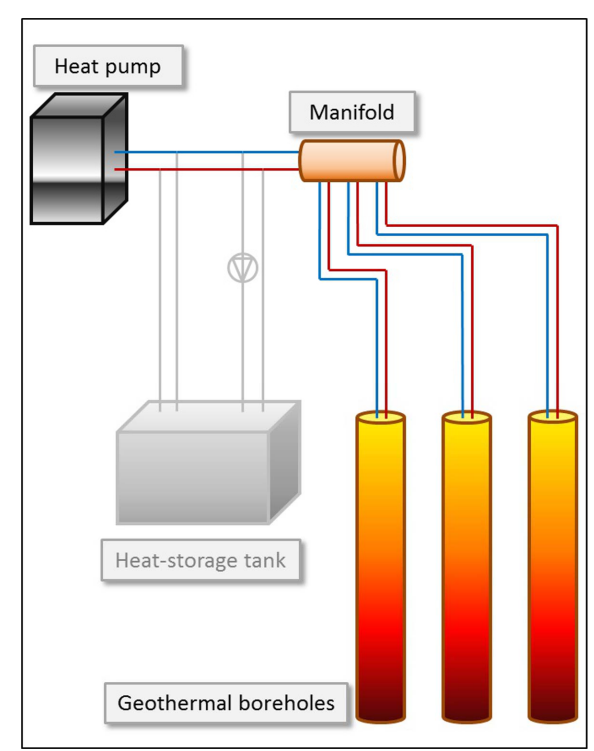

(a)

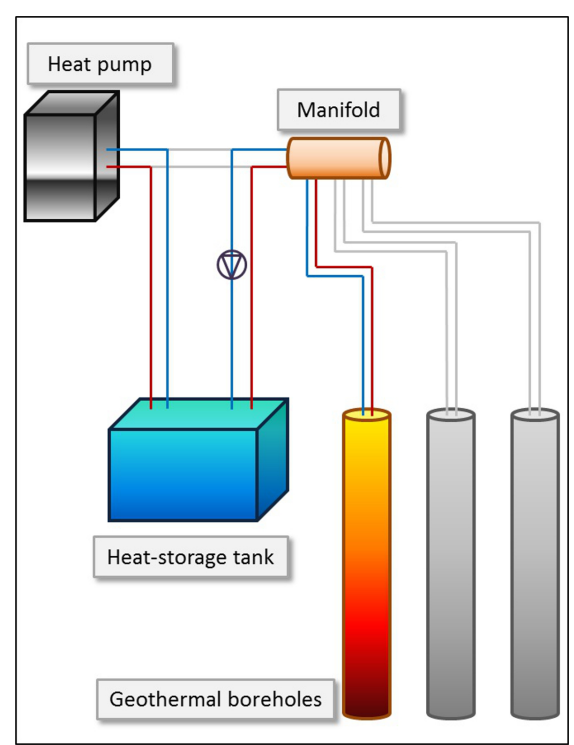

(b)

\subsubsection{Chip-Wood/Pellet Boiler with Li-Br Absorption Machine for Building No.2}

In building No.2, a $83 \mathrm{kWp}$ photovoltaic polycrystalline plant is installed on the roof and it supplies energy to cover the absorption machine and other electrical appliance needs. The biomass boiler is a FIREMATIC 100 Biocontrol, manufactured by HERZ Energietechnik GmbH Italia (San Vendemiano, Treviso, Italy), maximum heating capacity $100 \mathrm{~kW}$ (Figure 5a), equipped with a biomass storage of about $20 \mathrm{~m}^{3}$ gross volume (Figure $5 \mathrm{~b}$ ). The chip-wood is loaded through the sliding roof using special soft containers (i.e., big bags).

The Li-Br absorption cycle was preferred to the ammonia cycle because of the possibility of using lower process temperatures $\left(80-90^{\circ} \mathrm{C}\right)$, which can also be achieved by commercial biomass boilers. Few mono-bloc absorption chillers with peak cooling capacity lower than $100 \mathrm{~kW}$ are available on the market: a SYBCTDH70 chiller machine, manufactured by SYSTEMA S.p.A. (S. Giustina in Colle, Padova, Italy) was chosen (Figure 5c). The air/water cooling tower is incorporated in the machine and the power can be varied from $100 \%$ to $20 \%$, according to the cooling loads, thanks to an inverter control. 
Figure 5. Chip-wood/pellet boiler with $\mathrm{Li}-\mathrm{Br}$ absorption machine system: (a) the biomass boiler; (b) chip-wood storage; and the (c) Li-Br absorption machine.

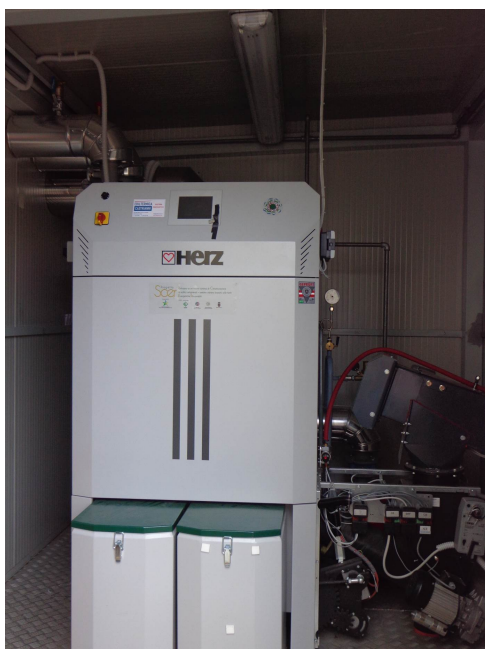

(a)

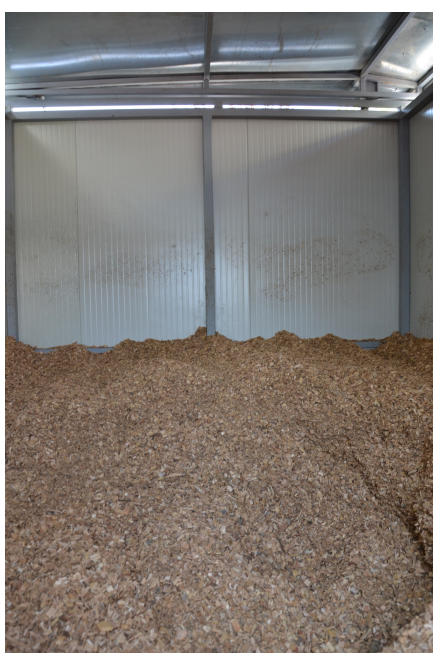

(b)

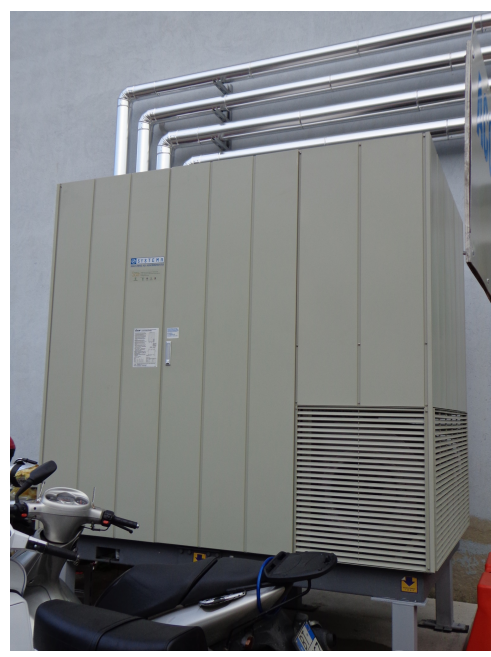

(c)

The chosen boiler can produce hot water with a temperature higher than $100{ }^{\circ} \mathrm{C}$, allowing a peak cooling capacity of $45 \mathrm{~kW}$; on the other hand, if the hot water temperature falls lower than $90{ }^{\circ} \mathrm{C}$, the cooling capacity decreases to $35 \mathrm{~kW}$. In the system layout, two utility buffers are included: the hot buffer (volume of $1000 \mathrm{~L}$ ), between the boiler and the absorption machine, and the cold one (volume of $500 \mathrm{~L}$ ), between the chiller machine and the fan-coils. Fan-coils (in the offices) and mixing air distribution systems (in exhibition room and mechanic's workshop) provide heating/cooling in building No.2.

\section{Experimental Section: Cooling Performance Results}

\subsection{Data Monitoring System}

The performance of the developed plants is monitored via custom data acquisition systems (DAQs). The two DAQs have been primarily designed to remotely monitor the functionality of each component (e.g., status of the machines), and the system performance (heat flows, flow rates, electric power, and temperatures). In addition, it is also possible to partially control the systems by remote (set temperatures and manual override of some of the components). All the variables are continuously acquired and locally stored. The GHP system has been equipped with a total of 33 sensors for temperature, electric absorption, pressure, water level in the tank, and cooling and thermal energy measurements and two control outputs. The boiler/absorption machine system has been equipped with several sensors in order to monitor: biomass boiler (power and energy supplied to the hot water, by means of a calorie counter, exhaust temperature, flow/return water temperatures); utility buffers (temperature and pressure); absorption machine (working temperatures, flow rates, water consumption in the evaporative tower); pumps (status, flow rate, water temperature); cooling capacity and energy supplied from the chiller by means of a calorie counter; total electric power and energy supplied to the system; fan-coils and mixing air distribution systems (status and temperatures); indoor air temperature. External temperature is also monitored in both the plants. 
The two DAQ systems are more accurately discussed in previous papers [45-47].

The GHP system was powered up in April 2013 and it was monitored for a total of 21 days at the end of the heating season: the system was tested in alternative mode, using the water tank and a reduced number of boreholes: the results of the winter campaign are discussed in previous papers [45,47]. The biomass boiler test took place at the beginning of June; now it is working with chip-wood for the building No.2 cooling [46]. In this section, the results of the summer experimental campaign for both the investigated systems are shown.

\subsection{Innovative GHP (System No.1)}

The cooling mode monitoring started on 19 July, right after the commissioning phase. A total of 13 days of data (up to $31 \mathrm{July}$ ) has been fully processed to analyze the system performance. The borehole temperature profile data is available until 18 August.

The system worked in alternative mode (Figure $4 \mathrm{~b}$ ): only one borehole was used with a constant flow rate set to $42.5 \mathrm{~L} / \mathrm{min}$. To avoid continuous on/off switching, the circulation pump is started when $\mathrm{T}_{\text {tank }}>\mathrm{T}_{\max }$ and it is stopped when $\mathrm{T}_{\text {tank }}<\mathrm{T}_{\min } . \mathrm{T}_{\min }=25{ }^{\circ} \mathrm{C}$ and $\mathrm{T}_{\max }=27{ }^{\circ} \mathrm{C}$ were chosen according to the preliminary testing results and they will be changed and optimized during the experimental campaign.

Figure 6 shows the working cycle of the system during a typical summer week (from 22 July to 28 July), with external air temperature equal to about $35^{\circ} \mathrm{C}$ in the afternoon.

Figure 6. Cooling working cycle: the power dissipated by the borehole [Pth geothermal (GT)], the thermal power pumped into the tank [Pth heat pump (HP) to take], taken off the building (Pth HP from building), and the electric power absorbed by the HP (Pel HP) are shown.

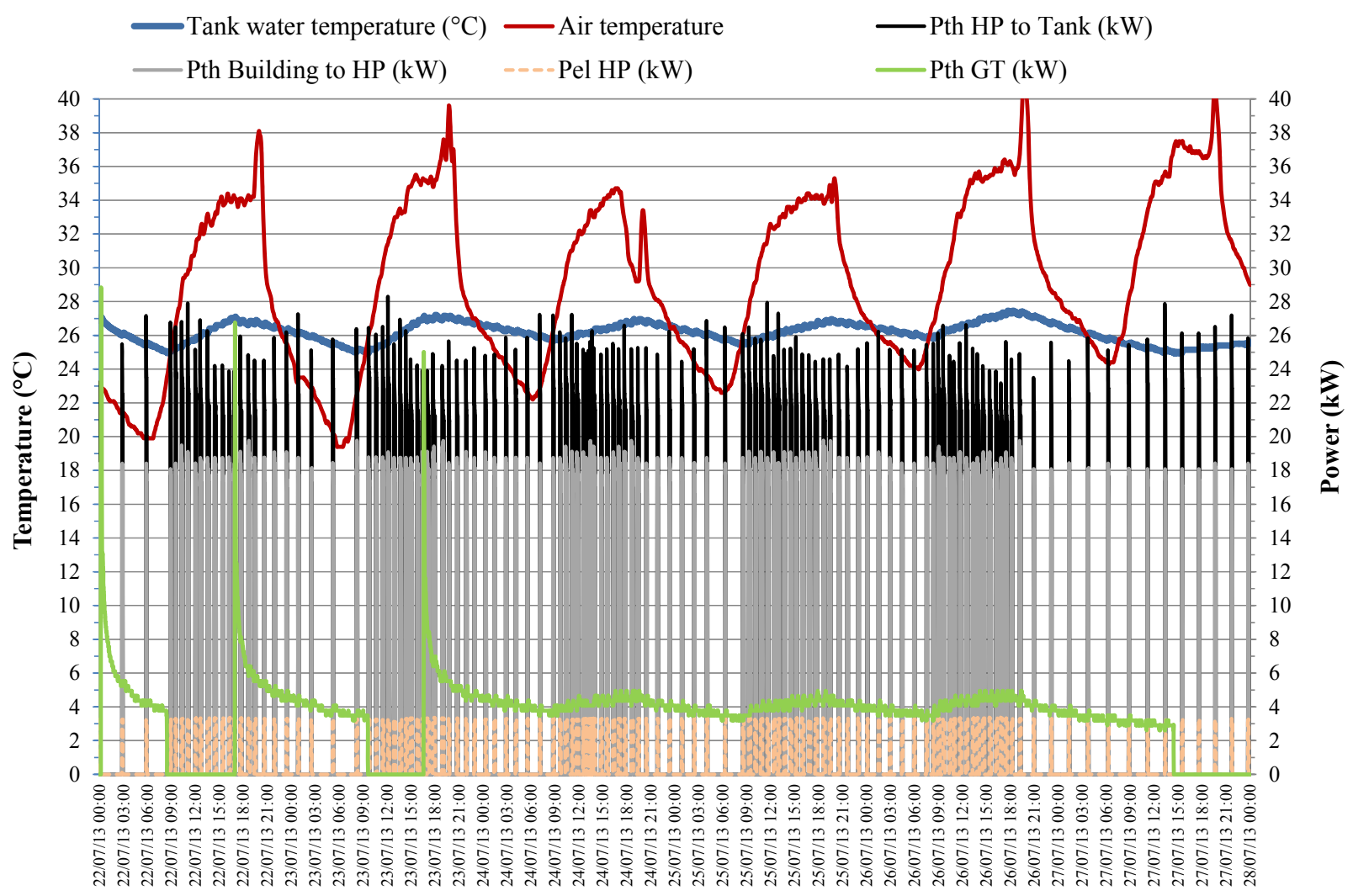


Starting from the initial conditions $\left(\mathrm{T}_{\text {tank }}=25^{\circ} \mathrm{C}\right)$, the tank temperature begins increasing when the $\mathrm{HP}$ is on (at 9:00 am); the GT pump is started only when $\mathrm{T}_{\text {tank }}$ is higher than $27^{\circ} \mathrm{C}$ (in the afternoon). During this period the tank temperature decreases; once HP is off, $\mathrm{T}_{\text {tank }}$ falls, and when this temperature is equal to $25{ }^{\circ} \mathrm{C}$, the GT pump is powered off. The average thermal power dissipated by the geothermal side, by the borehole No.1 only, is $4.4 \mathrm{~kW}$, with a duty cycle of $69.6 \%$.

On the other side, HP transfers heat at the average power of $22.1 \mathrm{~kW}$ to the tank and takes $18.5 \mathrm{~kW}$ out of the building, with a duty cycle of $14.2 \%$. During the test period an average thermal energy of $63.9 \mathrm{~kW} \mathrm{~h}$ /day has been taken off the building. An average EER equal to 5.0 was calculated for the HP.

The system is found to be stable. The tank water temperature shows the expected one-day cycle: the reduced-size geothermal unit is able to restore the initial conditions during the night time.

Figure 7 shows the temperature profile along the borehole from 19 July to 19 August. During the monitored period a power outage caused a stop of the monitoring system: the HP continued to pump heat inside the tank (its temperature exceeded $35^{\circ} \mathrm{C}$ ) but no heat exchange with the ground was provided. After the complete restart of the system it took a few days for the borehole to reach the initial working temperatures. The comparison between pre- and post-failure running temperatures shows that the geothermal field is able to work at the project conditions and to self-recover after periods of increased load. Anyway, a more consistent analysis of the ground response needs to be assessed after at least a one-year monitoring.

Figure 7. Temperature profile along the geothermal borehole. A power outage affected the monitoring system (from 2 August to 5 August).

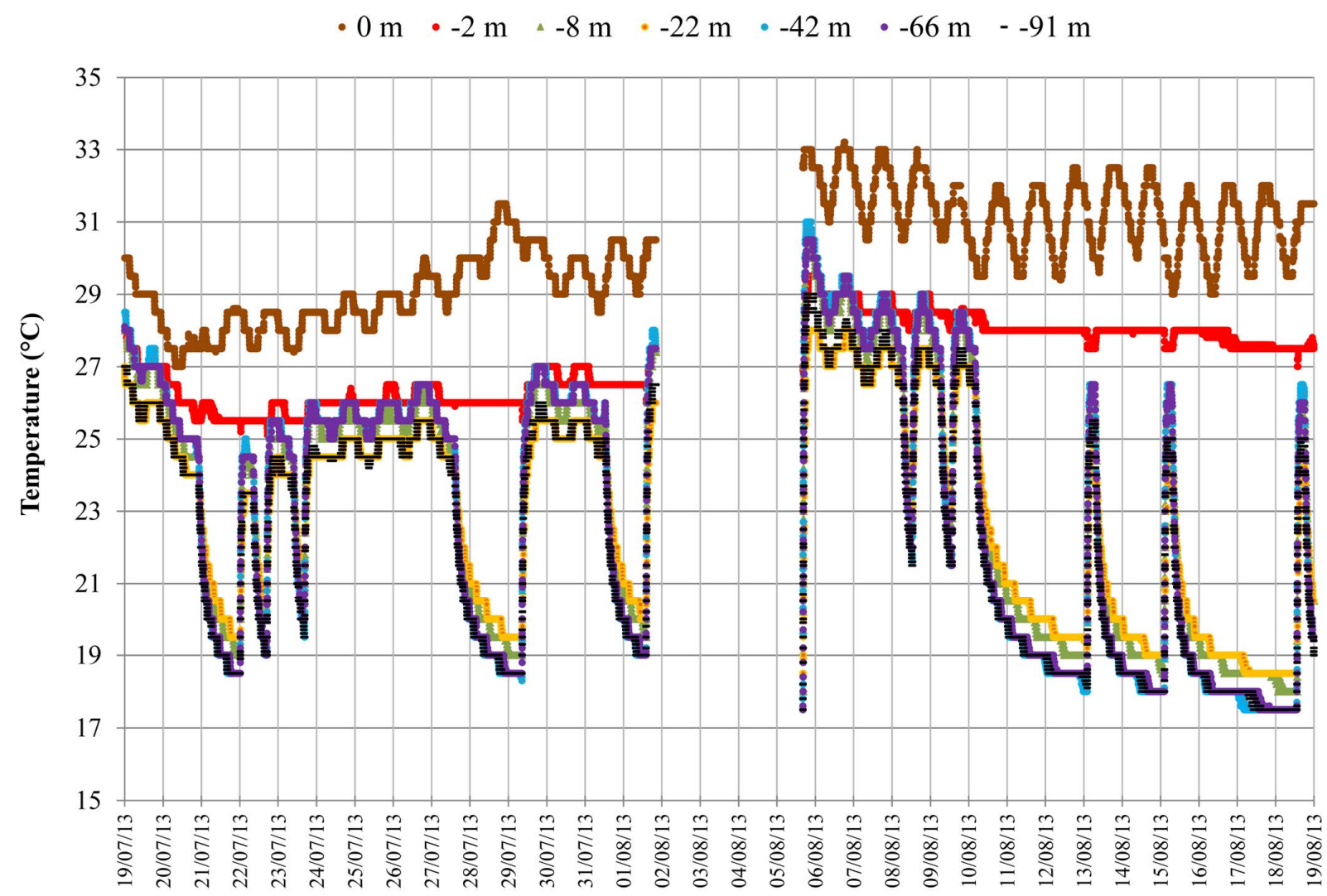




\subsection{Biomass Boiler with Absorption Machine (Biomass-Absorption Machine, System No.2)}

Figure 8 shows the working cycle of the system No.2 during the same summer week (from 22 July to 28 July). The biomass boiler, burning chip-wood, succeeds in producing hot water at about $104{ }^{\circ} \mathrm{C}$ and the absorption machine provides the cooling energy needs of the building, producing cooling water at about $10{ }^{\circ} \mathrm{C}$. Indoor comfort conditions were achieved in all the zones, also in the mechanic's workshop (average indoor temperature $=25^{\circ} \mathrm{C}$ ).

Figure 8. Weekly cooling working cycle of biomass boiler and absorption machine: the thermal power produced by the boiler, cooling power for the building, and the electric power absorbed by the system are shown.

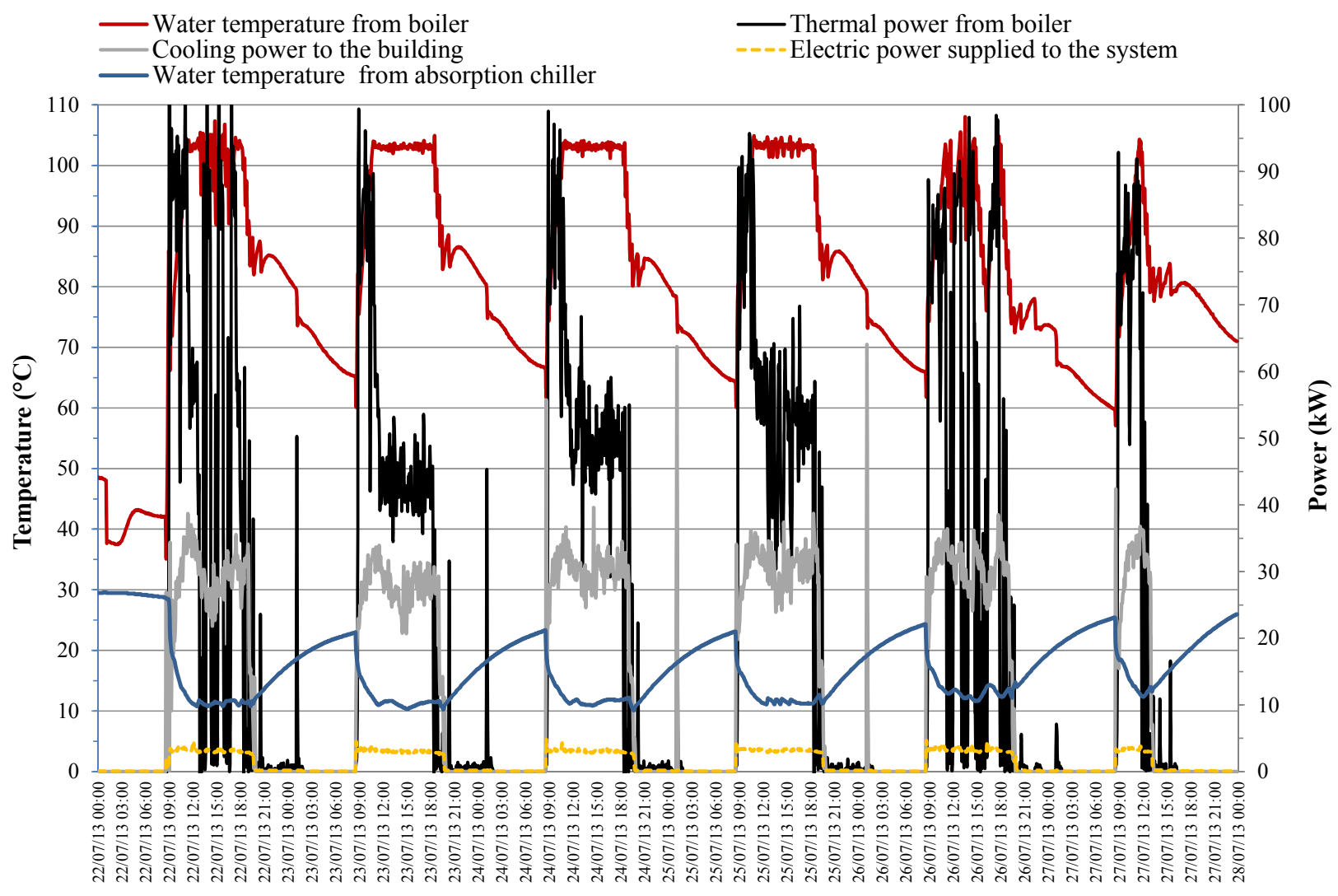

Thanks to the two utility buffers, the biomass boiler and the absorption machine could work independently: the boiler power depends on the hot buffer temperature and it is powered off at 6:15 p.m., while the chiller machine continues working up to 7:30 p.m. Considering a typical day (24 July), during the working cycle the cooling capacity was about $29.7 \mathrm{~kW}$, while the heat power from the boiler was about $51.4 \mathrm{~kW}$.

The performance of the system was evaluated in terms of global COP of the cooling system, calculated as the ratio between cooling capacity (given to the building) and the sum of the heat produced from the biomass boiler plus the electric energy absorbed by the system components: the machine components generator-absorber pumps, the pumps for the circulating fluids, and the evaporative cooling tower engine. During the test period, an average COP equal to 0.52 was obtained (referred to the whole system and not only to the absorption machine), in compliance with the data from literature [39]. During the investigated period, the cooling energy out of the absorption machine 
was 1.75 MW h, with an heat of 2.99 MW h from the boiler and a total electric absorption of about $197 \mathrm{~kW} \mathrm{~h}$ (Figure 9). As final remark, a water consumption of about $1.4 \mathrm{~m}^{3}$ each working day, due to the evaporative cooling tower, was observed (about $7.6 \mathrm{~m}^{3}$ in the tested week).

Figure 9. Energy trend during the test week.

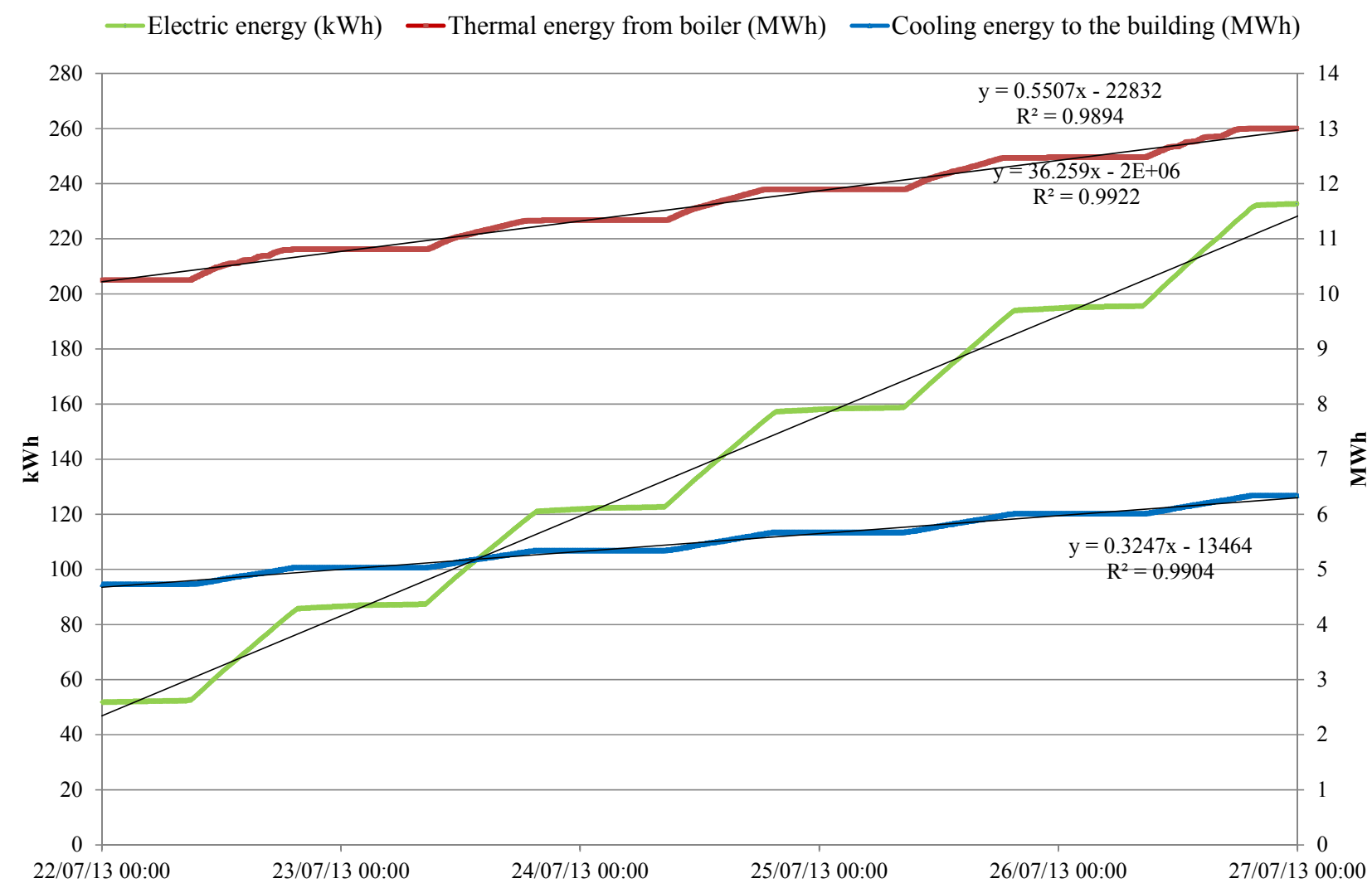

\section{Conclusions}

The setup and data analysis for two innovative heating and cooling systems for industrial and commercial buildings, using renewable energy (geothermal, biomass, and solar photovoltaic), are presented.

The innovative geothermal-driven heat-pump system features a heat-storage tank placed in series between the geothermal boreholes and the heat pump. The innovative design is based on the daily energy demand: the geothermal field is able to continuously exchange heat with the water tank, even when cooling (or heating) is off. The data analysis from the summer cooling operation, after the commissioning period, is presented. Based on the experimental results, a $12 \mathrm{~m}^{3}$ underground water tank successfully allows a reduced sizing of the geothermal field, while still providing the $24 \mathrm{~h}$ total energy need and covering the power peaks. While the conventional design would have required for three $5 \mathrm{~kW}$ boreholes to properly run the system, with the introduction of the heat storage tank, just one $5 \mathrm{~kW}$ borehole is sufficient to reach an EER equal to 5.0. The running temperatures and the overall performance are stable, featuring the expected one-day cycle. The borehole temperature profile was also monitored. Due to the limited available data, the long-term stability of the system (both the heating/cooling performance and the ground response) needs to be confirmed when yearly data will become available. 
The second system, a heating and cooling system using a biomass boiler and absorption chiller machine plant, is also found to be economically feasible and it presents environmental advantages. In particular, it is shown that the replacement of the standard layout for heating and cooling systems in commercial buildings represents a promising solution for energy and environmental issues. The main benefit of a thermally-driven absorption chiller is its lower electricity consumption if compared to an electrical compression chiller, and the production of renewable heat from biomasses drastically reduces the $\mathrm{CO}_{2}$ emissions. Moreover, integration with solar collectors could improve the performance and reduce the chip-wood consumption.

This applied research aims to demonstrate the actual feasibility of small-scale heating and cooling systems using renewable resources, and their potential especially in high-energy consumption commercial areas. At the same time, this approach could represent a significant solution to reduce greenhouse gas $\left(\mathrm{CO}_{2}\right)$ emissions, being all of the energy needs of the two systems covered by renewable sources. A direct quantification of the $\mathrm{CO}_{2}$ emissions associated to the systems [based on a life cycle assessment (LCA) approach] is currently ongoing. Future data analysis will focus on the complete season (summer and winter) performance monitoring, LCA of the plants, and economic feasibility.

\section{Acknowledgments}

This paper is based on the results obtained in the framework of the SCER (the Italian acronym for Development of a new Renewable-Energy Conditioning system for commercial buildings) Project. The project was co-financed by the Italian Ministry for the Environment and coordinated by the Biomass Research Centre (CRB) of the University of Perugia. The authors would like to thank everyone participating in this project: the Italian Ministry for the Environment, the Municipality of Perugia, and Consorzio Le Fratte. The authors also thank the following companies for the precious support during the system design, implementation, and monitoring of the proposed systems: Idrotermica Castrianni; Ciao Motori, Baldassarri B\&B; Idrotermica Frattegiani; Studio di Ingegneria Delta; Studio Associato Flu.Project.

\section{Conflicts of Interest}

The authors declare no conflict of interest.

\section{References}

1. The European Community. Directive 2009/28/EC of the European Parliament and of the Council of 23 April 2009 on the promotion of the use of energy from renewable sources and amending and subsequently repealing Directives 2001/77/EC and 2003/30/EC. Off. J. Eur. Union 2009, L140, $16-62$.

2. Valanciusemail, R.; Jurelionis, A.; Dorosevas, V. Method for cost-benefit analysis of improved indoor climate conditions and reduced energy consumption in office buildings. Energies 2013, 6 , 4591-4606. 
3. Tsagarakis, K.P.; Karyotakis, K.; Zografakis, N. Implementation conditions for energy saving technologies and practices in office buildings: Part 2. Double glazing windows, heating and air-conditioning. Renew. Sustain. Energy Rev. 2012, 16, 3986-3998.

4. Buratti, C.; Moretti, E. Glazing systems with silica aerogel for energy savings in buildings. Appl. Energy 2012, 98, 396-403.

5. Pisello, A.L.; Cotana, F.; Nicolini, A.; Brinchi, L. Development of clay tile coatings for steep-sloped cool roofs. Energies 2013, 6, 3637-3653.

6. Buratti, C.; Barbanera, M.; Fantozzi, F. A comparison of the European Renewable Energy Directive default emission values with actual values from operating biodiesel facilities for sunflower, rape, ad soya oil seeds in Italy. Biomass Bioenergy 2012, 47, $26-36$.

7. Buratti, C.; Moretti, E. Lighting and energetic characteristics of transparent insulating materials: Experimental data and calculation. Indoor Built Environ. 2011, 20, 400-411.

8. Buratti, C.; Moretti, E. Experimental performance evaluation of aerogel glazing systems. Appl. Energy 2012, 97, 430-437.

9. Johnston, I.W.; Narsilio, G.A.; Colls, S. Emerging geothermal energy technologies. KSCE J. Civil Eng. 2011, 4, 643-653.

10. The European Community. Directive 2010/31/EU of the European Parliament and of the Council of 19 May 2010 on the energy performance of buildings (recast). Off. J. Eur. Union 2010, L153, $13-35$.

11. Marszal, A.J.; Heiselberg, P.; Bourelle, J.S.; Musall, E.; Voss, K.; Sartori, I.; Napolitano, A. Zero energy building-A review of definitions and calculations methodologies. Energy Build. 2011, 43, 971-979.

12. Sartori, I.; Napolitano, A.; Voss, K. Net zero energy buildings: A consistent definition framework. Energy Build. 2012, 48, 220-232.

13. Sesana, M.M.; Salvalai, G. Overview on life cycle methodologies and economic feasibility for nZEBs. Build. Environ. 2013, 67, 211-216.

14. Pérez-Lombard, L.; Ortiz, J.; Pout, C. A review on buildings energy consumption information. Energy Build. 2008, 40, 394-398.

15. Seyboth, K.; Beurskens, L.; Langniss, O.; Sims, R.E.H. Recognising the potential for renewable energy heating and cooling. Energy Policy 2008, 36, 2460-2463.

16. Wahlund, B.; Yan, J.; Westermark, M. Increasing biomass utilisation in energy systems: A comparative study of $\mathrm{CO}_{2}$ reduction and cost for different bioenergy processing options. Biomass Bioenergy 2004, 26, 531-544.

17. Milenić, D.; Vasiljević, P.; Vranješ, A. Criteria for use of groundwater as renewable energy source in geothermal heat pump systems for building heating/cooling purposes. Energy Build. 2010, 42, 649-657.

18. Yang, H.; Cui, P.; Fang, Z. Vertical-borehole ground-coupled heat pumps: A review of models and systems. Appl. Energy 2010, 87, 16-27.

19. Self, S.J.; Reddy, B.V.; Rosen, M.A. Geothermal heat pump systems: Status review and comparison with other heating options. Appl. Energy 2013, 101, 341-348.

20. Li, Z.F.; Sumathy, K. Technology development in the solar absorption air conditioning systems. Renew. Sustain. Energy Rev. 2000, 4, 267-293. 
21. Escriva, E.J.S.; Sivila, E.V.L.; Frances, V.M.S. Air conditioning production by a single effect absorption cooling machine directly coupled to a solar collector field. Application to Spanish climates. Solar Energy 2011, 85, 2108-2121.

22. Buratti, C.; Barelli, L.; Moretti, E. Application of artificial neural network to predict thermal transmittance of wooden windows. Appl. Energy 2012, 98, 425-432.

23. Pisello, A.L.; Bobker, M.; Cotana, F. A building energy efficiency optimization method by evaluating the effective thermal zones occupancy. Energies 2012, 5, 5257-5278.

24. Buratti, C.; Moretti, E.; Belloni, E.; Cotana, F. Unsteady simulation of energy performance and thermal comfort in non-residential buildings. Build. Environ. 2013, 59, 482-491.

25. Chargui, R.; Sammouda, H.; Farhat, A. Geothermal heat pump in heating mode: Modeling and simulation on TRNSYS. Int. J. Refrig. 2012, 35, 1824-1832.

26. Ozyurt, O.; Ekinci, D.A. Experimental study of vertical ground-source heat pump performance evaluation for cold climate in Turkey. Appl. Energy 2011, 88, 1257-1265.

27. Kim, E.; Lee, J.; Jeong, Y.; Hwang, Y.; Lee, S.; Park, N. Performance evaluation under the actual operating condition of a vertical ground source heat pump system in a school building. Energy Build. 2012, 50, 1-6.

28. Michopoulos, A.; Papakostas, K.T.; Kyriakis, N. Potential of autonomous ground-coupled heat pump system installations in Greece. Appl. Energy 2011, 88, 2122-2129.

29. Aikins, K.A.; Choi, J.M. Current status of the performance of GSHP (ground source heat pump) units in the Republic of Korea. Energy 2012, 47, 77-82.

30. Michopoulos, A.; Bozis, D.; Kikidis, P.; Papakostas, K.; Kyriakis, N.A. Three-years operation experience of a ground source heat pump system in Northern Greece. Energy Build. 2007, 39, $328-334$.

31. Ozgener, O.; Hepbasli, A. Modeling and performance evaluation of ground source (geothermal) heat pump systems. Energy Build. 2007, 39, 66-75.

32. Yu, X.; Wang, R.Z.; Zhai, X.Q. Year round experimental study on a constant temperature and humidity air-conditioning system driven by ground source heat pump. Energy 2011, 36, 1309-1318.

33. Raymond, J.; Therrien, R.; Gosselin, L. Borehole temperature evolution during thermal response tests. Geothermics 2011, 40, 69-78.

34. Saidura, R.; Abdelaziza, E.A.; Demirbasb, A.; Hossaina, M.S.; Mekhilefc, S. A review on biomass as a fuel for boilers. Renew. Sustain. Energy Rev. 2011, 15, 2262-2289.

35. Demirbas, A. Potential applications of renewable energy sources, biomass combustion problems in boiler power systems and combustion related environmental issues. Prog. Energy Combust. Sci. 2005, 31, 171-192.

36. Lundgren, J.; Hermansson, R.; Dahl, J. Experimental studies of a biomass boiler suitable for small district heating systems. Biomass Bioenergy 2004, 26, 443-453.

37. Chau, J.; Sowlati, T.; Sokhansanj, S.; Preto, F.; Melin, S.; Bi, X. Techno-economic analysis of wood biomass boilers for the greenhouse industry. Appl. Energy 2009, 86, 364-371.

38. Porteiro, J.; Collazo, J.; Patino, D.; Granada, E.; Gonzalez, J.C.M.; Míguez, J.L. Numerical modeling of a biomass pellet domestic boiler. Energy Fuels 2009, 23, 1067-1075. 
39. Jakob, U.; Eicker, D.; Schneider, D.; Taki, A.H.; Cook, M.J. Simulation and experimental investigation into diffusion absorption cooling machines for air-conditioning applications. Appl. Therm. Eng. 2008, 28, 1138-1150.

40. Bassols, J.; Kuckelkorn, B.; Langreck, J.; Schneider, R.; Veelken, H. Trigeneration in the food industry. Appl. Therm. Eng. 2002, 22, 595-602.

41. Asdrubali, F.; Baldinelli, G.; Presciutti, A. Solar Cooling with Small-Size Absorption Chillers: Different Solutions for Summer Air Conditioning. In Proceedings of the XIII European Conference IIR - Centro Studi Galileo, Milano, Italy, 12-13 June 2009.

42. Martínez, P.J.; Pinazo, J.M. A method for obtaining performance correlations of absorption machines. Int. J. Therm. Sci. 2003, 42, 379-384.

43. Florides, G.A.; Kalogirou, S.A.; Tassou, S.A.; Wrobel, L.C. Design and construction of a LiBr-water absorption machine. Energy Convers. Manag. 2003, 44, 2483-2508.

44. Castro, J.; Oliva, A.; Perez-Segarra, C.D.; Oliet, C. Modelling of the heat exchangers of a small capacity, hot water driven, air-cooled $\mathrm{H}_{2} \mathrm{O}-\mathrm{LiBr}$ absorption cooling machine. Int. J. Refrig. 2008, $31,75-86$.

45. Bonamente, E.; Buratti, C.; Coccia, V.; Cotana, F.; Moretti, E.; Nicolini, A.; Palladino, D.; Passeri, F.; Petrozzi, A. Design and Monitoring of an Innovative Geothermal System Including an Underground Heat-Storage Tank. In Proceedings of the 5th International Conference on Applied Energy (ICAE), Pretoria, South Africa, 1-4 July 2013.

46. Cotana, F.; Buratti, C.; Moretti, E.; Barbanera, M.; Passeri, F. Feasibility and Environmental Advantages of a Plant with a Biomass Boiler and Absorption Chiller Machine. In Proceedings of the 68th Conference of the Italian Thermal Machines Engineering Association ATI, Bologna, Italy, 11-13 September 2013.

47. Cotana, F.; Moretti, E.; Bonamente, E.; Petrozzi, A. An Innovative Geothermal Heat-Pump System Including a Heat-Storage Water Tank: Development and Experimental Results. In Proceedings of the 68th Conference of the Italian Thermal Machines Engineering Association ATI, Bologna, Italy, 11-13 September 2013.

(C) 2013 by the authors; licensee MDPI, Basel, Switzerland. This article is an open access article distributed under the terms and conditions of the Creative Commons Attribution license (http://creativecommons.org/licenses/by/3.0/). 